\title{
RECONSTRUCTING WHITMAN'S DESK AT THE BROOKLYN DAILY TIMES
}

\section{KAREN KARBIENER}

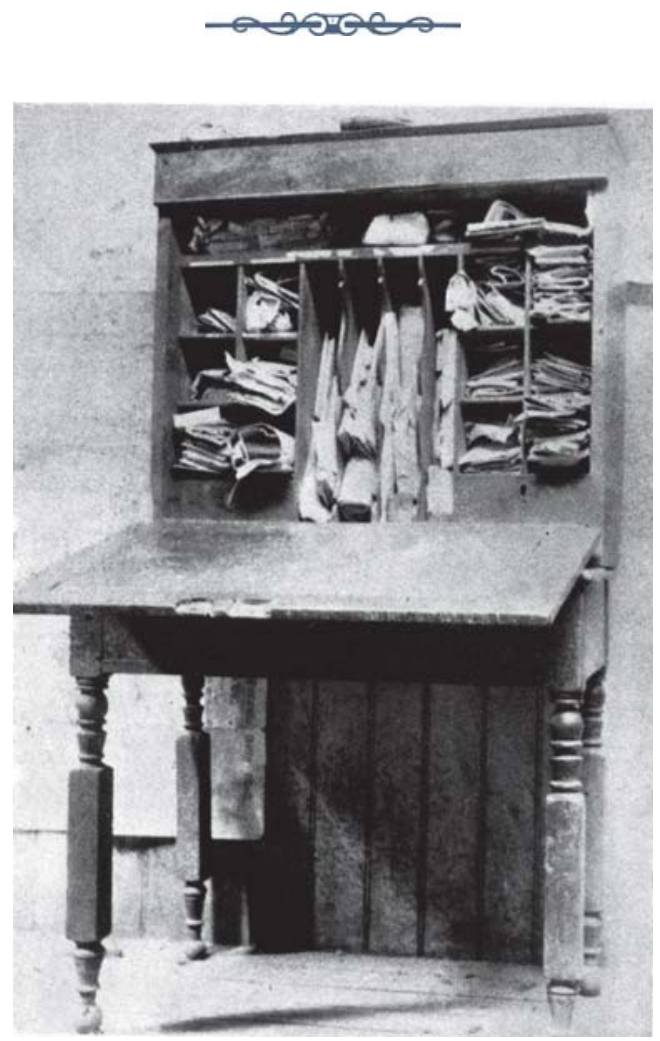

Figure 1. "Walt Whitman's desk in the Brooklyn Times office (1891)." From Alexander Black's Time and Chance: Adventures With People and Print (New York: Farrar and Rinehart, 1937), 74.

WHEN THE EDITOR of the Brooklyn Daily Times from 1885 to 1905 inherited what was known as "Walt Whitman's desk," his curiosity regarding the relic was piqued. ${ }^{1}$ Dissatisfied with the accounts of "survivors of an earlier day" who "knew about Whitman and his habits, and where the desk used to stand," Alexander Black took the story to its source in $1891 .{ }^{2}$ His letter of inquiry to Whitman was returned on May 12, along with Black's photo of the desk (see Figure 1). 
Couldn't remember distinctly enough to authenticate the desk . . . but I know I had a good time in the Times - \& heartily send my best respects \& love to the boys one \& all now there-I send my last photo: Tack it up if you like on the wall you all most congregate. ${ }^{3}$

A year later, Whitman was dead, and the desk-perhaps the only physical sign of his Times editorship — had fallen to pieces.

Whitman's editorship at the Times has become a standard part of his chronology since the publication of Emory Holloway and Vernolian Schwarz's I Sit and Look Out: Editorials from the Brooklyn Daily Times (1932). ${ }^{4}$ Holloway's twenty-seven-page "Introduction" sets forth Whitman's tenure from May 11857 to June 1859, his longest stay at any newspaper by several months; estimations of his editorial contributions outnumber those written for any other periodical. ${ }^{5}$ I Sit and Look Out remains the single book-length study of Whitman's work on the Times and the only easily accessible source of his editorials. ${ }^{6}$ And it has remained a source text for scholars recognizing Whitman's Times editorship, from Gay Wilson Allen to Dennis Renner. ${ }^{7}$

Yet Holloway and Schwarz's study has considerable flaws, leading some Whitman scholars to express doubts regarding the validity of their claims and even to request that the Times editorship be removed from Whitman's standard chronology. ${ }^{8}$ Holloway admits to his limited source materials ${ }^{9}$ - his account of the newspaper's history comes almost entirely from the Times' own sixtieth anniversary issue-and only 125 of what might be over 900 editorials are presented by subject rather than by date. As Jerome Loving has shown, Holloway and Schwarz made "inaccurate transcriptions" as well as "silent omissions" in their choices of editorials, tempering the political conservatism that does not seem to jibe with Whitman's radical literary experiments of the time. ${ }^{10}$ I Sit and Look Out was reprinted in 1966, but not updated since its first publication. In the 1960s, Herbert Bergman began assembling all of Whitman's journalism, including all of his editorials for the Times, for a comprehensive edition. His work remains unfinished, though Douglas Noverr and Jason Stacy are currently sifting through Bergman's notes for what will be the third volume of Whitman's journalism. ${ }^{11}$

This essay updates and expands Holloway's argument for Whitman's 
editorship of the Brooklyn Daily Times, and reexamines Holloway's proposed time span of Whitman's employment. Despite the lack of signed articles, staff boxes or Whitman's direct indication that he had edited the Times, compelling evidence exists for Whitman's tenure as at least a de facto editor. A "Calamus" manuscript with a Times editorial draft on its verso provides proof in Whitman's hand, and several convincing self-references reside in Times editorials. Though some of the articles seem out of character for Whitman - which might be explained by the domineering presence and editorial contributions of the paper's proprietor-others echo Whitman's writings published elsewhere. Furthermore, Whitman may have been on staff months earlier than Holloway's widely accepted start date of May 1, 1857. Like scholars before and after him, Holloway misunderstood the "period of compilation" and publication dates of the Brooklyn directories, though he relied upon them to calculate Whitman's tenure at the Times.

From as early as circa April 1856 to June 1859, Whitman's days were shaped by his work for the Brooklyn Daily Times. He probably wrote copy or edited content with regularity during these years. At the same time he was writing poetry for the third and possibly the second edition of Leaves of Grass. The Times supported this work in more ways than one: positive reviews of all three first editions of the Leaves framed his tenure there. Most importantly, the job kept him writing, reading, and in touch with literary culture when financial hardship might well have turned him into a professional real estate developer. Whitman's editorship of this upstart independent newspaper in the new city of consolidated Brooklyn coincided with a critical moment in his development as an artist. His desk must have held valuable information and perhaps a few keys to understanding what remains a relatively obscure period in his writing life. Surely it merits an attempted reconstruction.

\section{Recollecting Whitman's "good time in the Times"}

Walt Whitman never described himself as the editor of the Brooklyn Daily Times, though he claimed to have edited and written for the 
paper, dictated content, and influenced its position on politics and public concerns. He may have deliberately avoided the title because of the particular working conditions of this young and rapidly growing daily. Started in 1848 by George Bennett, Aaron Smith, and Egbert Guernsey, the Williamsburgh Daily Times fought to establish a readership in the independent city of Williamsburg, where four papers already competed for the public's attention. ${ }^{12}$ Its politically independent status and the "uncommon energy and ambition" of twenty-three year old Bennett helped the Times flourish. It moved from a "wooden shanty" to a three-story brick building in 1850 and congratulated itself that "we have a circulation larger than that of any other paper in town" in $1852 .{ }^{13}$ When Williamsburg consolidated with Brooklyn in 1855, the paper's potential readership grew and Bennett changed its name to the Brooklyn Daily Times to cater to the new market. Bennett became sole proprietor in 1856; in 1856 or early 1857, he hired Whitman, whose Leaves of Grass had been favorably reviewed in the Times on September 29, 1855 (for the first edition) and December 17, 1856 (for the second).

According to D.J. McAuslan, the Times' compositor in 1856, the staff that year was composed of a "business manager, an editor, and a reporter." ${ }^{\prime 4}$ Bennett was most probably the manager (or editor-inchief), with Whitman as editor and an additional staffer "reporting local news etc."15 But Bennett's dedication to the Times' success seems to have blurred the lines between these tasks, for he "still managed to take the leadership of the editorial staff." ${ }^{{ }^{16}}$ Did Bennett then write editorials as well? It would seem so. George C. Bennett is listed as the "Editor Brooklyn Daily Times" and "Editor and Proprietor of Brooklyn Daily Times" in Smith's 1856-57 Brooklyn City Directory and Lain's 1857-1858 Brooklyn City Directory, respectively, both of which also list Whitman as "editor." Letters written to the Times were sometimes addressed to the "Editors" as well as Bennett, "Editor," and "Mr. Editor." Whitman is mentioned as a staffer, but never designated as an editor, in the Times' three commemorative publications; and Whitman himself accepts without question the title of "editorial writer" from another Times employee. Further complicating the matter is W.A. Chandos-Fulton, author of a highly regarded serial report 
on the "Local Press of Brooklyn," who names Whitman the "first de facto editor" engaged at the Times. ${ }^{18}$ In all likelihood, both men wrote editorials for the paper, a theory that is supported by the unevenness of the content of the editorial page from early 1857 to mid- 1859 .

Whitman only wrote when prompted about his employment at the Times, but his connection with the newspaper became the stuff of legend at the office. ${ }^{19}$ Charles M. Skinner, editor of the Times from 1881 to 1885 , was the first employee to consult Whitman directly on the matter. ${ }^{20}$ On January 19, 1885, Whitman wrote "in hasty answer to [Skinner's] request asking me to specify over my own signature what years I worked as an editorial writer in the Brooklyn Daily Times."21

. . . I would say that if I remember right it was along in 1856, or just before. I recollect (doubtless I am now going to be egotistical about it,) the question of the new Water Works (magnificently outlined by McAlpine, and duly carried out and improved by Kirkwood, first-class engineers both,) was still pending, and the works, though well under way, continued to be strongly opposed by many. With the consent of the proprietor, I bent the whole weight of the paper steadily in favor of the McAlpine plan, as against a flimsy, cheap and temporary series of works that would have long since broken down, and disgraced the city.

This, with my course on another matter, the securing to public use of Washington Park (Old Fort Greene,) stoutly championed by me some thirty-five years ago, against heavy odds, during an editorship of the Brooklyn Eagle, are "feathers in my wings" that I would wish to preserve.

I heard lately with genuine sorrow of the death of George C Bennett. I remember him well as a good, generous, honorable man.

I send best greetings to your staff, and indeed to all the Brooklyn journalists. $^{22}$

Though he does not claim outright to have been editor, Whitman describes what could be understood as editorial sway over the Times in his support of the Brooklyn Water Works. He is accurate in his description of the project as being "well under way" in 1856-ground was broken for the Richmond Reservoir on July 30, thus inaugurating the Works - as well as continued delays to the completion of the plan, particularly in March $1857 .{ }^{23}$ Support for the Water Works was demonstrated regularly in Times editorials throughout Whitman's presumed tenure, extending even after completion of the project on December $12,1858 .{ }^{24}$ Nearly thirty years later, he remained proud of 
his role in the plan's approval. His note demonstrates that his Times campaign was as significant to him as his much better known efforts to establish what is now known as Fort Greene Park, as editor of the Brooklyn Daily Eagle. But Whitman is also aware that his work on the Times remained unrecognized. Though his comments about Bennett suggest that he had kept up on news about the paper, Skinner's inquiry indicates that the Times had not maintained organized records of its employees. ${ }^{25}$

Perhaps that is what motivated Skinner to write "Walt Whitman as an Editor," published in the Atlantic Monthly over 18 years after his exchange with the poet. The Times' poor record-keeping also helps explain why Skinner's article is more anecdotal than factual, and does not include a single quotation written by Whitman for the paper. "Whitman's tenure of office on the Times was not long," he notes vaguely:

In that office Whitman is but a tradition. It is remembered only that he was a tall, sturdy fellow, who had a habit of pacing the floor for a long time without speaking, though he could talk enough when he had provocation. ${ }^{26}$

About three columns of this eight-page article are dedicated to such stories of Whitman at the Times. Most of "Walt Whitman as an Editor" focuses on his work at the Eagle, where he "is a clearer memory than in the office of its contemporary."27 Numerous excerpts from Whitman's Eagle editorials are included.

For Skinner, proof of Whitman's editorship of the Brooklyn Daily Times resides in time-honored office gossip as well as a few objects Whitman left behind. Among these items were a "piece of shabby, battered furniture with small drawers, pigeon-holes, and a drop front, which was known as Walt Whitman's desk" and "a thin quarto entitled Leaves of Grass." It was Whitman's own copy, Skinner attested, "bearing his autograph on the flyleaf, and in the back he had pasted letters and criticisms on his work by Emerson and others."

To many of the reporters it was a source of mirth, of puzzle, of disgust, of admiration, according to temperament and understanding, and they tried to imitate its style for the funny column; yet they had a certain pride in this particular vol- 
ume, because Walt Whitman, its author, had been editor of the paper. ${ }^{28}$

Skinner's editorial successor Alexander Black, also notes that "signs of [Whitman] were taken for granted in that old newspaper shop near the Williamsburg ferry." Black shared Skinner's affection for the desk and corroborated his story about an in-house copy of Leaves of Grass "inscribed to an office mate." ${ }^{29}$ If the "desk copy" of the first edition of the Leaves held by Brown University is indeed the volume described by Skinner and Black, the person to whom it was "presented by the Author"—“Thos. D. Smith"-may provide a key to help unlock the mysteries of Whitman's years at the Times. ${ }^{30}$

After Whitman died and his desk fell apart, there were no further efforts made by Times staffers to research Whitman's editorship. In "The Fiftieth Anniversary of the Brooklyn Times," a 'good gray' portrait borders a description of Whitman, most of which is a statement by his coworker Frederick Huene. The longtime Times employee recalls Whitman's appearance, demeanor, and literary discussions, but offers nothing regarding Whitman's journalism or editorial labors. ${ }^{31}$ The article was reprinted in the "Sixtieth Anniversary Number" of February 28, 1908, in which another piece entitled "Days' Past in the Times Office" notes that "Bennett did not hesitate to stigmatize [Whitman] as the laziest and most useless man he ever met." 32 This theme is picked up by a pamphlet published for the Times' $68^{\text {th }}$ anniversary, in which Whitman is recognized as the first though not the finest of the Times' noted alumni:

Out into the wide world to win glory, or the more substantial rewards of genius and industry, have gone many who at one time or another wrote "copy" for the Brooklyn Daily Times.

Old Walt Whitman, the "good grey poet," was one of these. He stayed not long in the reportorial rank, nor did he leave it in a blaze of glory.

The tradition runs that he swept into the office with a breezy manner and a small gripsack, and was swept out after a brief and inglorious experience by the indignant Bennett who pronounced him "the laziest man who had ever put foot into the shop." It probably bothered Walt not at all, this parting expression of editorial disapproval, for he hied him to the Wild West and won for himself an undying fame. ${ }^{33}$

If Manhattan was this writer's idea of the "Wild West," his flip- 
pant critique of Whitman may also be an exaggeration; at best, it is a regurgitation of the undocumented notes in "Days' Past in the Times Office" or the charges leveled at Whitman by other newspapers. ${ }^{34}$ Strangely, this paper of record did not consult (or perhaps even maintain) records on its employees. ${ }^{35}$ Despite the lack of hard evidence regarding Whitman's employment as well as his alleged negative reputation, the Times continued to claim Whitman as one of its own.

\section{Rediscovering Whitman in the Pages of the Times}

The most convincing evidence of Whitman's editorial work on the Brooklyn Daily Times is in his own hand. On the verso of the manuscript pages for the poem "Calamus. 2" is a draft of an article entitled "Important Questions in Brooklyn." ${ }^{36}$ As Fredson Bowers suggests, this piece "seems to be a proposed editorial on the Brooklyn Waterworks for the Brooklyn Daily Times." After considering numerous Times editorials on the same subject and consulting with Gay Wilson Allen, Bowers suggests the publication date for the final draft as "shortly before 16 March 1859." No matter when or even whether this particular editorial was published, the existence of the manuscript demonstrates how closely Whitman's work for the Times coincided with his creative life. The point is further emphasized by Whitman's use of "City of Williamsburgh" tax forms for everything from drafts of poems to debt notices from 1857 through 1860. It is possible that these forms were printed and stored at the Times offices; when the city of Williamsburg became part of Brooklyn in 1855, they became obsolete and unusable for anything except scrap paper. ${ }^{38}$ Considering how much poetry he might have written on the job, it is unsurprising that Skinner and Black both saw Whitman's desk copy for the first edition of the Leaves in the office. His association with the Times may have interfered with his literary ambitions, but it also provided him with a place to write, perhaps even paper to write on.

If the Times enabled Whitman to compose poetry, his poetry also gave him the opportunity to work for the Times. Whitman's one established contribution to the Brooklyn Daily Times prior to his editorial work was unsigned, but demonstrates his early connection to the 
newspaper. "Walt Whitman, A Brooklyn Boy" appeared in the Times on September 29, 1855, and is one of three known self-reviews of the first edition of Leaves of Grass. The others- "Walt Whitman and His Poems," published in the United States Democratic Review in September 1855, and "An English and an American Poet" in the October 1855 issue of the American Phrenological fournal - were also published in journals with which Whitman had working affiliations. The Times' decision to publish this review demonstrates its support of Whitman as both poet and contributing writer, though Whitman was almost certainly not on staff in 1855 . Furthermore, "Walt Whitman, a Brooklyn Boy" is as personal and conversational as its title suggests. ${ }^{39}$ The review does not include any direct references to poetry but describes (as Floyd Stovall notes) the "poet's appearance and habits, as if the reviewer appealed particularly to the people of Brooklyn who might know him. ${ }^{240}$

The intimacy and humor of Whitman's Times review suggests that he had a good relationship with staffers as well as their audience. Considering the quick turnover of employees during these years, and the fact that the newspaper published a positive review of the second edition on December 17, 1856, it seems likely that Whitman had connected with George Bennett, the newspaper's proprietor. ${ }^{41}$ Bennett, who "still managed to take the leadership of the editorial staff" despite other obligations, is a strong candidate for the authorship of the second review. ${ }^{42}$ Edits to Whitman's promotional blurb of "A Child's Reminiscence" also indicate that someone at the Times in late 1859-Bennett again, presumably — was knowledgeable about Whitman's work. ${ }^{43}$ The poet seems to have considered readers of the Times as his own; likewise, Times staffers seemed to enjoy a familiarity with the poet.

If Whitman was held in such high regard at the Times, would not the paper want to announce his editorship proudly and publically? The paper's exclusion of staff boxes and bylines on articles and editorials was common practice in nineteenth-century American newspapers. ${ }^{44}$ Whitman himself had demonstrated an interest in authorial anonymity (and pseudonymity) from his earliest published writings. Traces of Whitman's presence can be found on the Times' editorial pages 
through the late 1850s. A commentary on streetcar service published on March 14, 1857 is signed "W.W." and concludes with the notice that "the writer intends to recur to this subject again"-as Whitman would in the Times and in other writings including Specimen Days. ${ }^{45} \mathrm{On}$ April 3, 1858, the editor mentions Whitman by name before relating memories of printing alongside "our friend" supervisor-elect William Cauldwell:

We cannot say, as R.W. Emerson did to the author of Leaves of Grass, "We greet thee on the threshold of a great career"; but we do say, with all our heart, full as it is, at the moment, of ancient reminiscences of many halcyon days passed with our friend Cauldwell, when we were both wont to read the Declaration of Independence on our cotton pocket handkerchiefs . . ${ }^{46}$

In 1901, Cauldwell published a letter in the New York Times recalling his encounters with Whitman in 1841, when Whitman was at the Aurora and Cauldwell at the Sunday Atlas. ${ }^{47}$

Appearances of other friends and acquaintances on the Times' editorial pages build the case for Whitman's connection with the paper. Near the beginning of Whitman's presumed tenure, a series of advertisements for Fowler and Wells' Phrenological Cabinet ran under "Special Notices"; these promotions for the Manhattan phrenologists stand out among the ads for local carpenters and dry goods stores, and may have been placed as a sign of support by Whitman's business associates. ${ }^{48}$ Around the same time, a two-columned editorial praising Henry C. Murphy identifies Whitman as the author in everything but name:

While still a youth, not more than twenty years old, Henry Murphy was possessed of fine talent. Brooklyn was then but a village. The writer of this remembers well the pleased surprise of young Murphy when he came into the "Long Island Patriot" office and found himself to be adjudged the writer of the "prize story" ... the writer of this was then a "devil," only twelve or thirteen years old himself ...

The piece includes specific recollections of "old Brooklyn" such as General Lafayette's visit, when "the writer of this, at that period six or seven years old" was "taken into the arms of Lafayette." 
Whitman's friend John Burroughs noted that he had "often heard speak of [the Lafayette incident]," and both this moment as well as Whitman's apprenticeship at the Long Island Patriot are recounted in similar language in "Brooklyniana," his serial essays for the Brooklyn Standard. ${ }^{50}$

It is tempting to see Whitman in the months of editorials dedicated to many of his favorite journalistic subjects: fresh water for New Yorkers, development of the East River ferry services, the support of citywide Sunday car service, local school reform, and critiques of his former employer, the Brooklyn Eagle. Though such Brooklyn-based editorials may well have been fair game for any editor of the Brooklyn Daily Times, their "peculiarities of diction, style, punctuation, and sentence structure" and the "repetition of Whitmanesque ideas" grant them the status of evidence of Whitman's authorship for both Holloway and Bergman; Bergman goes so far as to pronounce such indicators as "conclusive" proof. ${ }^{51}$ Though "conclusive" may be too strong a word, "convincing" comes to mind when reading the descriptions of particular Long Island sites in an editorial entitled "Long Island is a Great Place:"

The South side - the Great South Bay — the fishing and fowling — the fisherman, the natives, the curious and original characters, so quaint, so smacking of salt and sea-weed-the wrecks and wreckers-all these richly repay the journeyer and explorer, from Rockaway to the Hamptons. ${ }^{52}$

Whitman's enduring interest in exploring and documenting Long Island was recorded in his "Eastern Long Island Correspondence" for the Brooklyn Daily Eagle (September 16, 18, and 20, 1847), the eleven "Letters From a Travelling Bachelor" appearing in the Nerw York Sunday Dispatch (1849-1850), "Letters from Paumanok" for the New York Evening Post (1851) and "Brooklyniana" (for the Brooklyn Standard, 1861-62.). As Charles Feinberg has noted, Whitman gathered a great body of materials for the purpose of writing a local history through the $1850 \mathrm{ss}^{53}$ This enthusiasm is palpable in the language of this editorial, which continues:

our readers may soon expect in our columns a running series of letters, depicting 
the places, scenes, shores, improvements, and the salient traits of the people also, through Long Island, penned con amore from the same hand as the foregoing. ${ }^{54}$

This thread is picked up again in "Our Island" on July 31, with the reiterated intention to write a "less dry" Long Island history. ${ }^{55}$ Whitman's fondness for writing in serial may also be recognized in "Williamsburgh Word Portraits," a series of 18 character sketches published in the Times from May 18 to June 6, 1859 that echo Whitman's "Sketches of the Sidewalks and Levees" and his sixteen "Paragraph Sketches of Brooklynites" 56 The last number, a tribute to a school teacher, focuses on a favored Whitman theme that pervades this issue of the Times: an editorial entitled "A Word to Parents Who Have Children in School" demands an active parental role in education, and an anti-Lancastrian anecdote advises to "burn the rod and spare the child." 57

As "Whitmanesque" as Holloway and Bergman found the editorials during Whitman's presumed tenure at the Times, others have failed to recognize his voice consistently on the editorial page. Jerome Loving argues forcefully against Whitman's editorship of the Times based on two points: the lack of empirical evidence; and the observation that "most of the editorials [attributed to Whitman] are politically conservative at a time when Whitman was radicalizing American poetry theme as well as manner." 58

Whitman's possible years at the Times run from the presidential campaign of 1856 to the beginnings of the heated debates preceding the 1860 election. Though the paper supported the Republican candidate John Frémont in 1856, and came to favor the Republican Lincoln in the 1860s, it maintained its independence through the years between, adopting an anti-extremist view rather than clearly taking a side. For example, in its thin coverage of the Lincoln-Douglas debates of 1858, the Times cautiously supported Douglas for his independence from any party line and moderate position on slavery. ${ }^{59} \mathrm{With}$ local elections, too, Times editorials urged readers to vote "for principle over party." While supporting the candidacy of a local Brooklynite over the incumbent for city office, the Times editor sneers, "Are we so prejudiced in favor of slavery, that we agree with the President and Mr. Maclay in keeping Free Kansas out of the Union, until she has double the popula- 
tion necessary to admit her as a Slave State? ${ }^{{ }^{\prime 0} 0}$ But strong anti-slavery activism was also subject to sarcasm: six months earlier, abolitionists were described as an "isolated association of men and women, black and white, of enthusiastic and often noble intentions, but sick, scornful of the people, and even partially insane." ${ }^{\prime 1}$ The editor steers readers towards a middle ground or free soil position, rather than a politically conservative one. As Loving himself notes, even editorials such as "Prohibition of Colored Persons"-which finds reasons to favor Oregon's new constitution prohibiting African Americans from entering the state ${ }^{6}$ — represent the "casual racism" exhibited by "most other nineteenth-century white Americans, who opposed slavery but were not convinced that blacks were equal to whites." ${ }^{93}$

Yet through the late 1850s, there are unusual variances of opinion on key political and social issues on the Times editorial pages. Eight months after proclaiming that Blacks could "never" achieve status as "capable," "self-reliant" or "mighty" freemen in America, ${ }^{64}$ the editor asks his audience to attend a lecture by the "celebrated speaker and writer" Frederick Douglass:

He is "right smart," and figures prominently in the history of the times. Those who belive that the colored race have "rights which the white man is bound to respect," and who desire to see how far they are susceptible of cultivation and development, should be on hand tomorrow night. ${ }^{65}$

How may the editor's negative view on African Americans in May 1858 be reconciled with his encouraging words in January 1859? Certainly there should be an allowance for change of heart; both Whitman and the Brooklyn Daily Times did grow more supportive of the Republican anti-slavery platform over time. But other discrepancies of opinion can be explained less easily. An 1857 editorial on "Our Daughters" offers a view on female education that for Loving sounds far removed from the liberated view of women in Leaves of Grass, and advises parents to "educate [their daughters] at home" rather than send them to "one of those caravanseras denoted as boarding-schools." same newspaper offers an argument for "Women's Rights in the New Library:" 
Yes, women too must have a chance at study, mental improvement-not forgetting physical development. In the first points, either a large room should be appropriated to them-or, what would be better yet, they should come and go, in the general room, reading, writing, taking out books, indiscriminately with the men. At first it might look strange, but it would soon settle down to feel all right; and would probably have a salutary effect all around. ${ }^{67}$

In the same week that this editorial was published, the Times described the 'free love' position on women's rights as "the best illustration yet of certain curious wandering phases of the American mind" 68 and the controversial female preacher Lydia A. Jenkins as "mak[ing] a very fair discourse." ${ }^{\prime 9}$ The rights of women was a favorite subject of Times editorials, but the paper did not hold a steady position on the topic over months, even over days.

Nor did the editor maintain a consistent stance on the death penalty, another hot topic for Whitman and the Times. As Loving points out, the Times editor includes "romantic penny-a-liners and sympathetic old ladies" among the opponents of capital punishment on January 13,$1858 ;^{70}$ this does not sound like the journalist who spoke out against the death penalty in dozens of pieces through the 1840s. ${ }^{71}$ Four months later, the editor recollects attending meetings on the "capital punishment question" "some years ago," when writers for the Democratic Review "made some of the most powerful attacks yet seen, against the orthodox theory of capital punishment." The benefit of this opposition was

in the good resulting out of the discussion, in such ways as diffusing more benevolence and sympathy through the public mind, elevating the range of temper and feeling, and reacting in a hundred different modes, indirectly, upon the popular taste, and upon criminal law, the doings of courts and juries, and the management of prisons. These, along with other considerations... will amply repay the enthusiasts of the Democratic Review, and those who have labored with them, for all they have done. ${ }^{72}$

This piece could easily have been written by Whitman, recollecting his anti-capital punishment activism as a writer for the Democratic Review. But could he just have easily have mocked "soft-hearted (and soft-headed) prison philanthropists" in an article on the same subject, only weeks before? 
Most probably, the Brooklyn Daily Times had more than one writer penning its editorials. Considering Bennett's economic, political and personal investment in his newspaper, it is not difficult to imagine that he demanded space on the editorial page. The confusion regarding who the editor or editors were is sometimes palpable: on August 23, 1858, for example, "Mr. Bennett" is addressed in one of the letters to the editor, while another begins with "Editors." As much as some pieces sound like Whitman's, others bear a very different style and tone-perhaps reflecting the social and political differences of the two men. Bennett was born in London in 1824, moved to Manhattan at age 12 and settled in Brooklyn in 1847; as a native Brooklynite, Whitman knew the Times' readership better than did its proprietor. Bennett was younger, married, and would eventually have four children; he was also politically ambitious and maintained an active public life, eventually selling the Times in order to serve as city assemblyman and Commissioner of Public Works. ${ }^{73}$ And he was reportedly "so soaked in Shakespeare (recall he was English) that no lesser poet could hope to find favor in his eyes." ${ }^{74}$ Though Whitman was also a Shakespeare fan, he was hardly as exasperated by his fellow New Yorkers (or as disapproving of men's bloomers, which he wore himself) as the writer of this Times editorial:

Bubble bubble toil and trouble! What a curious medley the women's rights meetings present! Where but in New York could such a collection be got together? Women in breeches, men in petticoats - white, black and cream-colored, atheists and free-lovers, vegetarians and Heaven-knows-what - are all mixed together "thick and slab" until the mixture gets a little too strong, we should think, even for metropolitan stomachs. ${ }^{75}$

Whitman's reasons for leaving the Times in 1859 remain a mystery, though it seems clear that two such strong-minded editors would encounter problems sharing a page and an office.

\section{Reconsidering Whitman's Tenure at the Times}

Almost as difficult as proving Whitman's editorship of the Times, is ascertaining the starting and ending dates of his employment. In the "Introduction" to I Sit and Look Out, Holloway proposes that Whit- 
man's tenure ran from "the first of May, 1857, and possibly earlier" to sometime in June 1859, admitting to the difficulty of fixing precise dates. ${ }^{76}$ The evidence he relies on for the May $1^{\text {st }}$ date is Whitman's listing as "editor" in Smith's Brooklyn Directory of 1856-57.7 In a note, Holloway explains that "William H. Smith's Brooklyn Directory for 1857, whose period of compilation ended May 1, 1857, lists him as an editor, and gives his residence as 91 1/2 Classon Avenue." ${ }^{.78}$ Holloway relies on this evidence twice in his "Introduction," the second time explaining "that he was in charge of the paper on May 1, 1857, has been shown by a citation of the city directory." that Whitman assumed the editorship "possibly earlier" than that date and includes two earlier articles in an appendix entitled "Articles of Possible Whitman Authorship," Holloway begins his chronology of Whitman's editorship on the seemingly safe date of May $1 .{ }^{80}$ "May 1857 " or "Spring 1857 " has thus been the accepted starting-date of Whitman's editorship of the Times in sources from Walt Whitman: An Encyclopedia to the "Chronology of Walt Whitman's Life" at the Whitman Archive. ${ }^{81}$

Holloway made significant errors, however, in his use of the directories to stabilize his argument in I Sit and Look Out. He misunderstood the "period of compilation" as well as the publication dates for the directories. Holloway notes that Whitman is listed as "editor" in Smith's Brooklyn Directory for 1856-57, "whose period of compilation ended May 1, 1857" and hence was published on or after that date. ${ }^{82}$ In fact, this directory was published on June 3, 1856, as announced in the Brooklyn Daily Eagle of June 4, 1856: "The new Brooklyn Directory is published June 3 1856-Smith's Brooklyn Directory of 1856-57." ${ }^{33}$ Holloway missed the publication date printed within the directories (which is indeed 1856 in the 1856-57 issue), and the fact that the compilation period was traditionally forty days or so before publication. ${ }^{84}$ "May 1" is cited in several directory titles because it was Brooklyn's traditional "moving day." ${ }^{85}$ With so much displacement occurring at that time, compilers wisely began their canvassing periods after that date and could be reasonably sure that addresses would remain relatively stable for one year. Hence Smith's Brooklyn Directory for the Year Ending May 1ts, 1857 was compiled and printed by June 3, 1856 and 
then relied upon through May 1, 1857, when information for a new directory would be gathered.

Holloway was thus over a year off in his understanding of the information in Smith's Brooklyn Directory for 1856-57. It was between early April and June 3,1856, though probably earlier in this period when Whitman publically declared his employment as "editor." $\mathcal{}$. Lain's Brooklyn City Directory (Consolidated) for the Year Ending May 1", 1858 confirms that Whitman claimed editor status again in mid-1857. ${ }^{87}$ The possibility exists, then, that Whitman may have begun some regular form of employment with the Brooklyn Daily Times in April 1856. As radical as it may seem to move the beginning date of his tenure over a year earlier than the traditional "May 1857" designation, Whitman himself noted that "if I remember right it was along in 1856, or just before" that he worked as an "editorial writer" for the Times. ${ }^{88}$ Whitman's notorious inaccuracy with dates has led scholars to favor Holloway's dates over Whitman's own, though to Whitman's credit he might be thinking quite loosely about his work for the paper. After all, his self-review of the first edition of Leaves of Grass appeared in the Brooklyn Daily Times of September 29, 1855.

Whitman's two listings might be explained in other ways, of course. He may have claimed editor status of two different publications during the two canvassing periods, possibly Life Illustrated for mid- $1856^{89}$ and the Times for mid-1857. The new information regarding Whitman's two citations as "editor" does not help clarify when he began working for the Times, though it does establish that Holloway's start date of May 1, 1857 is arbitrary: Whitman may have been editing the Times for months (possibly a year) before that date. Interestingly, even Holloway suspected Whitman's presence on the Times editorial page before his proposed start date, and so includes two "Articles of Possible Whitman Authorship"-from January 30 and March 14, 1857-in an appendix. ${ }^{90}$ Such pieces, and indeed the editorial pages for the Times from early 1856 through May 1857 deserve close scrutiny for Whitman's presence.

As for the length of his tenure, Holloway's suggested end-date of June 1859 is supported by indicators that Holloway himself had not considered. Two separate series of Times editorials—one on Brooklyn 
ferries through February 1859, the other on Brooklyn's Water Works that extends to April 1859- bear strong resemblance to Whitman's work elsewhere. Further proof that these editorials were Whitman's is supplied by a draft for a Times editorial on the verso of the manuscript for "Calamus 2"; as was explained earlier in this essay, Bowers dates the draft as written on or around March 16, 1859."91

The Brooklyn directories for this period both complicate and assist in establishing the termination date for Whitman's Times editorship. Neither Walt nor his family appears in Lain's 1858-59 directory, though Whitman was listed in Lain's directory of the year before, and had been included in at least one directory per year since 185455. Somehow, Whitman and his family escaped public record during the canvassing period of this edition, between May 1 and early June 1858..$^{22}$

Both Walt and his mother reappear in the Brooklyn City Directory for the Year Ending May 1 ${ }^{\text {st }}$, 1860. During the May $1^{\text {st }}$ to early June 1859 canvassing period for this edition, Whitman was recorded as:

Whitman Walt. copyist, Portland av. n. Myrtle av

Whitman's mother Louisa is entered as a widow at the same address. It is the first time Louisa is listed, the last time her son is listed - and the only time Whitman is described as a "copyist" in the Brooklyn directories. Other entries on the same page are listed as "editor," so the use of "copyist" in Whitman's case was deliberate. It is unlikely that the word was employed as a shorthand term for "copy editor." Whitman himself used the word in its traditional definition of "one who copies" in "Chants Democratic. 13"; perhaps his employment as copyist while drafting the poem led to this negative association:

There shall be no subject but it shall be treated with reference to the ensemble of the world, and the compact truth of the world-And no coward or copyist shall be allowed. ${ }^{4}$

By early June 1859, then-not June 1860, as Roger Asselineau and others have assumed ${ }^{95}$ - Whitman earned money as a transcriber of documents. His financial situation was strained by the middle 
of that year; ${ }^{96}$ yet he seems to have resigned rather than been fired from the Times, ${ }^{97}$ and parted on terms amicable enough to describe Bennett as a "good, generous, honorable man" twenty-five years later. ${ }^{98}$ Even just a few months after his resignation, he selected the Times as one of three Brooklyn newspapers to advertise for his new poem "A Child's Reminiscence." The fact that a positive blurb on Whitman and his poem appeared in the Times on December 24, 1859, also suggests that he had not left his desk on bad terms.

And there it stands, as upright and unplumbed as Whitman himself. The desk of an editor, or perhaps a co-editor or 'editorial writer' as Whitman seemed to prefer; but certainly a sign of some authority in the office. A hideaway, too, for a man with two faces: a hack thinking about word count, a poet thinking about words.

He scribbles on one face with a blunt pencil:

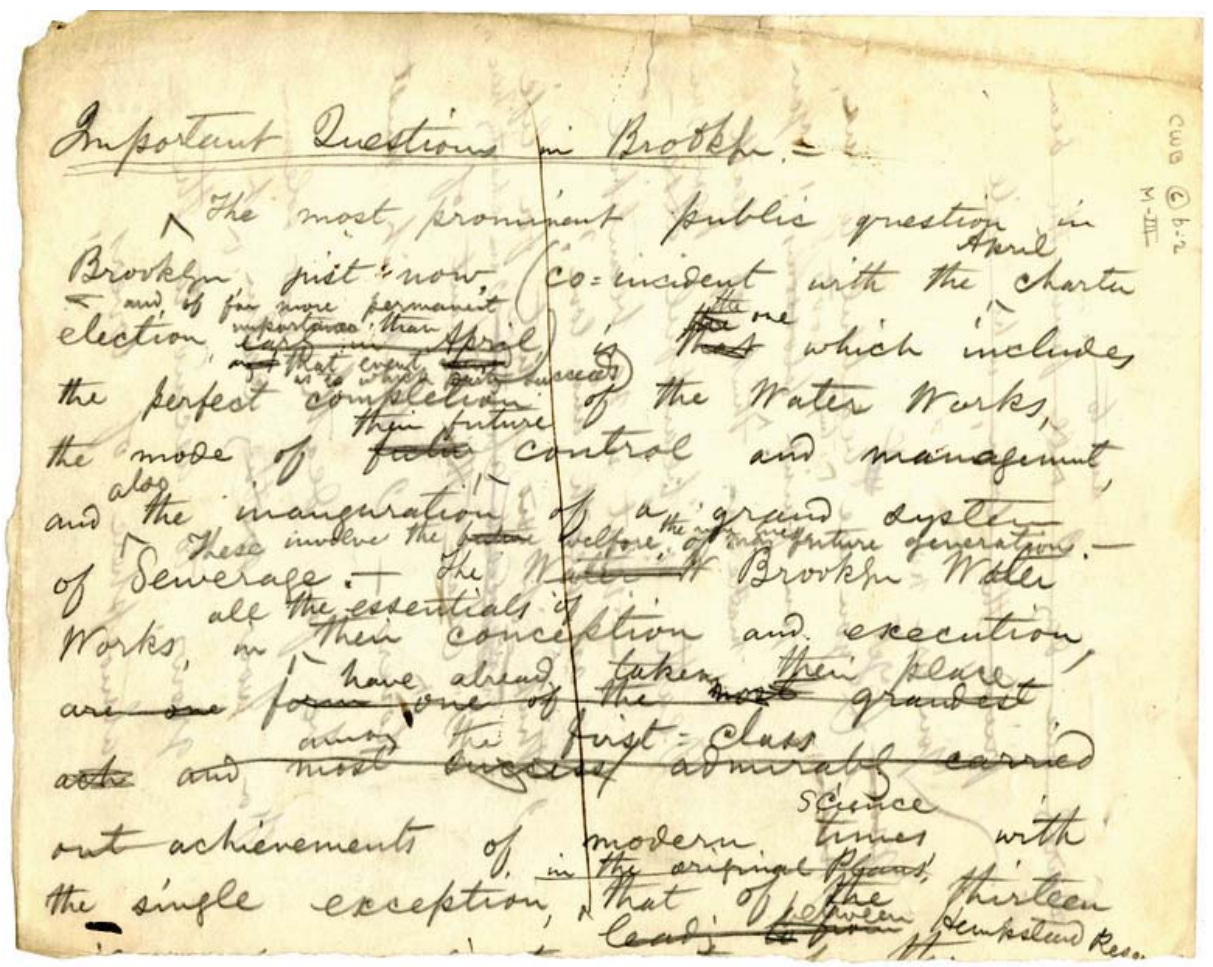

Figure 2: Whitman's draft of editorial on Brooklyn Water Works, verso of Figure 3. Papers of Walt Whitman (MSS 2829), Clifton Waller Barrett Library of American Literature, Albert H. Small Special Collections Library, University of Virginia. 
WWQR Vol. 33 No. 1 (Summer 2015)

He labors for a while at the draft. And then relenting, he puts down the pencil, turns the sheet over, takes up his fountain pen and presses more deeply:

Sur os one on 9 an do find the dean

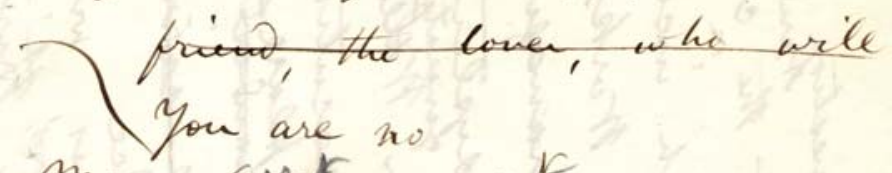

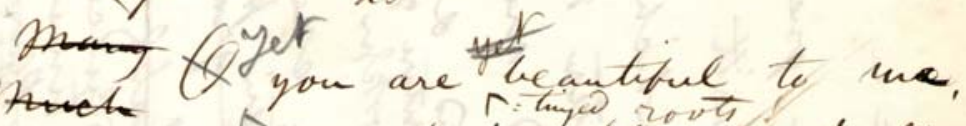
jon faint your tors! you make ma think of death, Death is beautiful atom ion.

- What is so beanlifue as death and love?

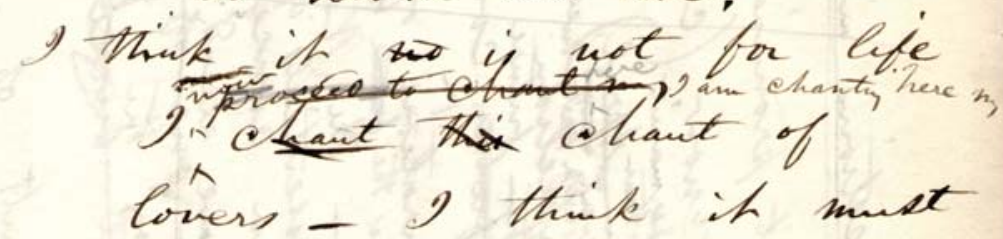

he for death, how solemn

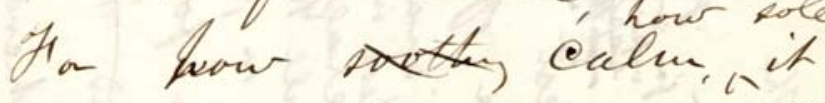
grows, to ascent to the atmosphere of Covers,

Figure 3: Whitman's draft of "Calamus.2." Papers of Walt Whitman (MSS 2829), Clifton Waller Barrett Library of American Literature, Albert H. Small Special Collections Library, University of Virginia.

40 
He slides the leaf with four others into one of the cubbyholes. Rising easily from the desk, he pockets a handful of old tax forms and strolls out of 12-14 South Seventh Street north towards the Grand Street Ferry.

\section{New York University kk55@nyu.edu}

\section{NOTES:}

1 This essay responds to recent skepticism regarding Whitman's editorship of the Brooklyn Daily Times. The information presented helps ground and validate my argument in "Bridging Brooklyn and Bohemia: How the Brooklyn Daily Times Brought Whitman Closer to Pfaff's," in Joanna Levin and Edward Whitley, eds., Whitman Among the Bohemians (Iowa City: University of Iowa Press, 2014), 1-18, a discussion of the role of Whitman's Times editorship in his development as an artist.

2 Alexander Black, Time and Chance: Adventures With People and Print (New York: Farrar and Rinehart, 1937), 72. See also William White, "An Uncollected Whitman Letter to Alexander Black," Walt Whitman Quarterly Review 1 (1983), 63.

3 Walt Whitman to Alexander Black, May 12, 1891. Available on the Walt Whitman Archive (www.whitmanarchive.org, ID: loc.07066)

4 Emory Holloway and Vernolian Schwarz, eds., I Sit and Look Out: Editorials from the Brooklyn Daily Times (1932; reprinted New York: AMS Press, 1966).

5 In Walt Whitman: An Encyclopedia, Dennis K. Renner notes "over 900 items" were written by Whitman while at the Times; Charles Oliver claims Whitman wrote "more than 1200 pieces for the Times" in his Companion to Walt Whitman. Herbert Bergman claims that he read "over 12,500 pieces" to develop his lists of Whitman's contributions to both the Brooklyn Eagle and the Times. See J.R. LeMaster and Donald D. Kummings, eds., Walt Whitman: An Encyclopedia (New York: Garland, 1998), 82; Charles Oliver, ed., Companion to Walt Whitman (New York: Facts on File, 2006), 262; and Herbert Bergman, “On Editing Whitman's Journalism," Walt Whitman Review 16 (December 1970), 108.

6 The Times remains largely inaccessible for the $1855-1860$ period. As of October 2015, the newspaper has not been digitized, and microfilm for these five years is rare. For this essay, I consulted the Times microfilm at the Brooklyn Public Library, the only institution with a complete set of the 1006 reels of film from its beginnings as the Williamsburgh Daily Times in 1848 through 1932, when it bought out the Brooklyn Standard Union and became the Brooklyn Times-Union. Joy Hol- 
land, the Division Chief of the Brooklyn Public Library's Brooklyn Collection, was very helpful in all matters from access to source materials for the Brooklyn Daily Times.

7 See Gay Wilson Allen, The Solitary Singer: A Critical Biography of Walt Whitman (New York: New York University Press, 1955, rev. 1967), 208-216; and Dennis Renner's article on the "Brooklyn Daily Times" in Walt Whitman: An Encyclopedia, 81-82.

8 Scholars Jerome Loving and Ted Genoways have voiced doubt concerning Holloway's argument for Whitman's editorship of the Times. See Loving's Walt Whitman: The Song of Himself (Berkeley: University of California Press, 1999), 227-232, and Genoways' Walt Whitman and the Civil War (Berkeley: University of California Press, 2009), 7-8. In his review of Roy Morris' The Better Angel, Loving returns to his critique of I Sit and Look Out; he reminds readers that in Walt Whitman: The Song of Himself he found Holloway's assertion of Whitman's editorship "unfounded. When I examined that claim, I found it almost completely baseless, and I now believe it ought to be stricken from the standard Whitman chronology." See Jerome Loving, "Review of Roy Morris Jr., The Better Angel: Walt Whitman and the Civil War," Walt Whitman Quarterly Review 18 (Winter 2001), 152.

9 Holloway and Schwarz, 202, n. 19.

10 Loving, Song of Himself 230, 227.

11 Thanks to Ed Folsom, Doug Noverr, and Jason Stacy for sharing this information via email. Bergman writes of the problems of editing Whitman's work for the Times and other periodicals in his article "On Editing Whitman's Journalism." Bergman's twisted prose reflects the difficulty of his task: "Only several individual items in the Eagle and the Times, on the basis solely of internal evidence, could definitively be said to be his; however, the external evidence is conclusive and the repetition of Whitmanesque ideas is so prevalent as to indicate one man, Whitman, wrote all the editorials . . . [N]o editorials or leading articles in the Times could be proved to be not by Whitman" (108). At the same time, Bergman notes that "the use of a computer to authenticate Whitman's authorship proved unfeasible because of the lack of distinctive stylistic traits: Whitman's style varies with the subject matter, mood, and occasion ... [I]n the writings of George C. Bennett, who might have written for the Brooklyn Daily Times, it was impossible to distinguish between his style and that of Whitman" (105).

12 The town of Williamsburgh became the city of Williamsburg in 1852, when its spelling was changed.

13 "Sixty Years of Newspaper Making," Brooklyn Daily Times Sixtieth Anniversary Number (February 28, 1908), 3.

14 "Sixty Years of Newspaper Making," 3.

15 This would jibe with the account an "old-time newspaper man" gave in 1898 
of "former days in the Times office": the "city editor" of the Times wrote while the "editor-in-chief... bossed things." See "Former Days in the Times Office," Brooklyn Daily Times, February 26, 1898, 3:1.

16 "Sixty Years of Newspaper Making," 3.

17 Bergman also noted this in his essay "On Editing Whitman's Journalism," 106.

18 W.A. Chandos-Fulton, "Local Press of Brooklyn," Brooklyn Standard 10 (November 5 1864). This was a highly regarded series of articles-referenced, in fact, by the eminent Brooklyn historian Henry Reed Stiles in his History of the City of Brooklyn, Vol. 3 (Brooklyn: Published by Subscription, 1870), 927.

19 Whitman only wrote when prompted about his employment at the Brooklyn Daily Times. He leaves out mention of the Times in Specimen Days, though he does describe editing the "daily Eagle" in "1848, "49" and the Brooklyn Freeman in the early 1850s (he actually edited the Eagle from 1846-1848 and the Freeman from 1848-1849). See Walt Whitman Prose Works 1892, Vol. 1, ed. Floyd Stovall (New York: New York University Press, 1963), 21-22. Whitman's notebook \#87 at the Library of Congress is rich in autobiographical data and includes notes on several newspapers, but breaks off after 1848. See Whitman, Notebooks and Unpublished Prose Manuscripts, Vol. 1, ed. Edward F. Grier (New York: New York University Press, 1984), 209-211.

20 Skinner was also a noted folklorist as well as an editorial writer and drama and art critic for the Brooklyn Daily Eagle. For details on Skinner's life, see his New York Times obituary of December 21, 1907. In "Another Look at Charles M. Skinner," John Bealle notes that Skinner edited the Times until 1884; yet Whitman sends his reply of January 19, 1885, back to Skinner at the Brooklyn Daily Times offices. See Bealle's article in Western Folklore 53 (April 1994), 104; and Whitman, Correspondence, Vol. 3, ed. Edwin Haviland Miller (New York: New York University Press, 1964), 385.

21 Whitman seems satisfied with reusing Skinner's term "editorial writer" instead of "editor," once again calling into question Whitman's actual role on the Brooklyn Daily Times.

22 Walt Whitman to Charles M. Skinner, January 19, 1885. Available on the Walt Whitman Archive (www.whitmanarchive.org, ID: loc.03812). Whitman included another envelope to Skinner marked "Private" demonstrating his interest in making this history public: "You are at liberty to print letter, if you desire-if so read proof very carefully $\mathcal{E}$ copy_\& don't forget to send me here a couple of papers."

23 George Brainard, The Water Works of Brooklyn: A Historical and Descriptive Account of the Construction of the Works... (Brooklyn: n.p., 1873), 9.

24 See, for example, a note criticizing the Long Island Farmer's caution regarding the expanding Works in the Times of March 5, 1857; "A Visit to the Water Works" on April 17, 1858; early plans for "The Water Celebration" on December 6, even 
before their completion; and almost daily editorials from February 1859 in preparation for the Water Celebration on April 28, capping off with "The Moral of the Water Celebration" (April 30). These editorials are on p. 2 of each Times issue. Later in this essay, I propose that Whitman may have begun working for the Times earlier than Holloway's suggestion of May 1857; the consistency with which the subject of the Water Works is treated from March 1857 and the lack of such editorials through January and February 1857 suggest that Whitman may have begun writing for the Times in March.

25 The Times' carelessness regarding its own history is manifested in other ways. Documents published to celebrate its anniversaries either lack or remain vague about historical data on its staff or content; see, for example, the booklet "The Brooklyn Daily Times is Sixty-Eight Years Old," which contains a listing of "Alumni of the Times" without positions or time frames; and the article on "Sixty Years of Newspaper-Making," which is exactly the same as a piece published ten years prior. Compare "The Brooklyn Daily Times is Sixty-Eight Years Old; Therefore this Birthday Dinner in the Brooklyn Club" (March 25, 1916), 4; and "The Fiftieth Anniversary of the Brooklyn Times," Brooklyn Daily Times (February 26, 1898), Sect. 3, 1, with "Sixty Years of Newspaper-Making," 3.

26 Charles M. Skinner, "Walt Whitman as an Editor," Atlantic Monthly 92 (1903), 679 .

27 Skinner, "Walt Whitman as an Editor," 680.

28 Skinner, "Walt Whitman as an Editor," 679.

29 Black notes several Whitman relics in the Times office, including the copy of Leaves of Grass, in The Latest Thing and Other Things (New York: Harper, 1922), 163-164; and also in Time and Chance, 72.

30 See the copy of the first edition of Leaves of Grass in the Harris Collection of Hay Library designated 1-SIZE WW A2 1855 copy 1. It is described in the record as "Whitman's desk copy" and includes, as per Skinner's statement, tipped-in galley proofs of reviews of the book (including one from the Brooklyn Daily Times) and a rare broadside printing of Emerson's letter on the publication of Leaves of Grass. A penciled note signed "T.D. Smith" explains that the volume "was handed to the writer on his departure for the West in 1855, this copy being the last of the edition, and from his table."

31 "The Fiftieth Anniversary of the Brooklyn Times," Sect. 3, 1.

32 “Days' Past in the Times Office," Brooklyn Daily Times Sixtieth Anniversary Number, 5.

33 "The Brooklyn Daily Times is Sixty-Eight Years Old: therefore this birthday dinner in the Brooklyn Club, March twenty-fifth, nineteen hundred and sixteen" (Brooklyn, N.Y.: The Paper, 1916), 4. This seems to have been the last of the Times' commemorative publications before the newspaper ceased in 1932; I have 
checked the Times from January 2 through March 31, 1918 (its $70^{\text {th }}$ anniversary), January 3 through March 30, 1923 (its $75^{\text {th }}$ ), and February 1 through March 31, 1929 (its $80^{\text {th }}$ ) and found no follow-up commemorations to its celebration of its $50^{\text {th }}$ on February 26, 1898, its $60^{\text {th }}$ on February 29, 1908, and its $68^{\text {th }}$ on March 25, 1916. I am grateful to Elizabeth Call, then a Special Collections Librarian at the Brooklyn Historical Society, for bringing my attention to "The Brooklyn Daily Times is Sixty-Eight Years Old."

34 Whitman was accused of laziness by his employers at the New York Aurora, the Brooklyn Daily Eagle, and other newspapers. See Loving's discussion of the Aurora in Walt Whitman: The Song of Himself, 56-59, and Oliver's entry on the Eagle in the Critical Companion to Walt Whitman, 260.

35 The Brooklyn Daily Times' carelessness with its records affected its legacy: after it ceased publication in 1932, its morgue was eventually absorbed by the Brooklyn Daily Eagle. Joy Holland, Division Chief of the Brooklyn Public Library's Brooklyn Collection, notes that the "Library received the morgue and some Eagle files in 1957, but as far as I know nothing that we now have here can be identified as having belonged to the Brooklyn Daily Times" (email to author dated November 20, 2012). Whatever records the Times might have kept are apparently lost.

36 See the manuscript for "Scented Herbage of My Breast" (MSS 3829) in the Papers of Walt Whitman, Clifton Waller Barrett Library of American Literature, Albert H. Small Special Collections Library, University of Virginia. The first four of the manuscript's five pages have notes for an editorial on the Brooklyn Water Works on their versos.

37 Fredson Bowers, Whitman's Manuscripts: Leaves of Grass (1860), A Parallel Text (Chicago: University of Chicago Press, 1955), xxviii, xxix.

38 Under the masthead of the Williamsburgh Daily Times, Bennett advertised for "Printing of Every Description." The Times printed other official documents for the City of Brooklyn as well, such as the Manual of the Common Council of the City of Brooklyn for 1856, 1858-1859 and 1859-1860 and the Charter for the City of Brooklyn in 1857. See "Check List of General Serial Municipal Documents of Brooklyn in the New York Public Library, 31 December 1901." Bulletin of the New York Public Library Volume 6 (January-December 1902), 13, 15. For a discussion of Whitman's use of these tax forms, see Bowers, xli-xliii. Bowers notes "the probability that [Whitman] secured [the tax forms] only when he came to edit the Brooklyn Daily Times" but does not suggest that the forms were actually printed in the Times offices (xliii). It is also possible that Andrew Rome printed the tax forms and gave them to Whitman, as the Rome brothers printed many legal documents for Brooklyn and remained friendly with the poet through this period.

39 The review was meaningful to Whitman as well: he reprinted it in the "Opinions" section of the second edition of the Leaves, where it included a reference to phrenology as well as his phrenological chart. It also appears in Leaves of Grass 
Imprints, in which Whitman incorrectly lists the origin of the review "From the Brooklyn Daily Times (1856)." See Leaves of Grass Imprints, ed. Walt Whitman (Boston, Thayer and Eldridge, 1860), 30-32.

40 Floyd Stovall, The Foreground of Leaves of Grass (Charlottesville: University Press of Virginia, 1974), 3.

41 See "Sixty Years of Newspaper Making," 3.

42 Floyd Stovall is uncertain about the authorship of this review; see Stovall, The Foreground of Leaves of Grass, 3. Charles Gaylor, Whitman's editorial predecessor at the Times, is an unlikely candidate; he wrote an extremely negative parody of Whitman in Momus, Gaylor's short-lived comic daily. See Holloway and Adimari, New York Dissected, 182. Considering the paper's staff as described in "Sixty Years of Newspaper Making," two likely authors of the review were either Bennett or the reporter responsible for 'local items.' See "Sixty Years of Newspaper Making," 3.

43 The Times advertisement even corrects what seems to be a mistake in Whitman's draft, changing "Walt Whitman, after two years' silence, gives a new poem" to "Walt Whitman, author of 'Leaves of Grass,' who shot so suddenly into the literary heavens three years ago." For Whitman's draft advertisement, see Amanda Gailey, "Walt Whitman and the King of Bohemia: The Poet in the Saturday Press," Walt Whitman Quarterly Review 80 (Spring 2008), 147. The actual advertisement ran in the Brooklyn Daily Times (December 24, 1859), 2.

44 No articles in the Brooklyn Daily Times had bylines between January 1857 and June 1859; only letters to the editor were occasionally signed. Through these years, "By George C. Bennett" was written below its masthead. Bennett was not named as editor, nor was a staff box included.

45 "The Rights and Convenience of the Mechanics of Brooklyn, and their Families, Demand the Running of the City Cars on Sundays," Brooklyn Daily Times (March 14 1857), 2. The Times' editorial pages focused on the so-called "Sunday Car Question" through April 8, 1857. Whitman's continued interest in this subject is exhibited in numerous editorials and is highlighted in "Omnibus Jaunts and Drivers" from Specimen Days in Prose Works 1892, 1:14.

46 Untitled editorial, Brooklyn Daily Times (April 3, 1858), 2.

47 The letter is reprinted in Conserving Walt Whitman's Fame: Selections From Horace Traubel's Conservator, 1890-1919, ed. Gary Schmidgall (Iowa City: University of Iowa Press, 2006), 80-82.

48 The ad ran from May 27 through June 2, 1857. Though the Times editor wrote positively about Life Illustrated in "The Two Systems" (November 6, 1858), "phrenologists" were belittled along with "free-lover, ultra-abolitionists" and others in "The Radicals in Council" (June 29, 1858)-yet another example of the "identity crisis" of the Times' editorial page. 
"Henry C. Murphy," Brooklyn Daily Times (June 3, 1857), 2.

50 John Burroughs, "Introduction" to Lafayette in Brooklyn by Walt Whitman (New York: George D. Smith, 1905), n.p. Whitman's "Brooklyniana” series was published between 1861 and 1862; number 6 contains memories of his printing apprenticeship, and number 8 elaborates on Lafayette's Brooklyn visit. See Uncollected Poetry and Prose of Walt Whitman, ed. Emory Holloway (Garden City, NY: Doubleday, 1921), 2:245-249 and 2:253-257.

51 Holloway and Schwarz, 17; Bergman, "On Editing Whitman's Journalism," 108.

52 "Long Island is a Great Place," Brooklyn Daily Times, July 30, 1857, 2.

53 Feinberg, Charles. An Exhibition of the Works of Walt Whitman Commemorating the One Hundredth Anniversary of the Printing of His Leaves of Grass (Detroit, MI: Detroit Public Library, 1955), 1.

54 "Long Island is a Great Place," 2. Holloway and Schwarz leave out this last paragraph in their reprinting of this editorial in I Sit and Look Out.

55 “Our Island," Brooklyn Daily Times (July 31, 1857), 2.

56 For text of "Sketches of the Sidewalks and Levees" (New Orleans Crescent) and one of his "Character Sketches of Brooklynites" (Brooklyn Daily Advertiser, May 18-June 6, 1850), see Uncollected Poetry and Prose, 1:199-218 and 1:234-235.

57 "A Word to Parents Who Have Children in School" and untitled article, Brooklyn Daily Times (June 6, 1857), 2.

58 Loving, Song of Himself, 227.

59 "Douglas's success in Illinois is a triumph of which he may well be proud," writes the Times editor; "It is a victory of the independent Representative over the party dictator, of one brave man struggling alone, in the strength of his personal popularity and his great oratorical powers, against the Administration in his front, and the opposition in his rear... [I]t affords him now the opportunity of organizing a great middle conservative party, neither proscribing slavery, like Seward, nor fostering it, like Buchanan." See "Senator Douglas's Success," Brooklyn Daily Times (November 5, 1858), 2.

60 Untitled editorial, Brooklyn Daily Times (November 1, 1858), 2.

61 "Abolitionists Abound," Brooklyn Daily Times (May 12, 1858), 2.

62 "Prohibition of Colored Persons," Brooklyn Daily Times (May 6, 1858), 2.

63 Loving, Song of Himself, 230, 232.

64 "Prohibition of Colored Persons," 2.

65 "Fred. Douglass," Brooklyn Daily Times (January 6, 1859), 2.

66 “Our Daughters," Brooklyn Daily Times (September 25, 1857, 2); Loving, Song 
of Himself, 229.

67 "Women's Rights in the New Library," Brooklyn Daily Times (May 8, 1858), 2.

68 "Women's Rights—Free Love With a Vengeance," Brooklyn Daily Times (May 14, 1858), 2.

69 "A Woman in the Pulpit," Brooklyn Daily Times (May 17, 1858), 2.

70 Loving, Song of Himself , 229; "The Death Penalty," Brooklyn Daily Times (January 13, 1858), 2.

71 For more on Whitman's involvement with the anti-capital punishment movement, see Paul Christian Jones, "'That I could look... on my own crucifixion and bloody crowning:' Walt Whitman's Anti-Gallows Writing and the Appeal to Christian Sympathy," Walt Whitman Quarterly Review 27 (Summer 2009), 1-27.

72 “Capital Punishment," Brooklyn Daily Times (May 22, 1858), 2.

73 Biographical information on George Bennett obtained from his "Obituary" in the Brooklyn Daily Eagle (January 4, 1885), 5.

74 "Days' Past in the Times Office," 5.

75 Untitled editorial, Brooklyn Daily Times (May 14, 1858), 2.

76 Holloway and Schwarz, 8, 12-20. Holloway's name alone appears on the "Introduction."

77 Holloway and Schwarz, 17.

78 Holloway and Schwarz, 202.

79 Holloway and Schwarz, 17.

80 Holloway and Schwarz, 8, 179-184.

81 See also Joann Krieg, $A$ Whitman Chronology (Iowa City: University of Iowa Press, 1998), 37; Allen, 208.

82 Holloway and Schwarz, 202.

83 Brooklyn Daily Eagle (June 4, 1856), 3. Available online at the Brooklyn Public Library's Brooklyn Collection Newsstand: bklyn.newspapers.com/image/50252628

84 For 1856-1857, two Brooklyn directories were published; interestingly, Hope and Henderson's Brooklyn City Directory claimed the compilers at Smith's Brooklyn Directory had not heeded the traditional commencement of canvassing on May 1. In an unpaginated note "To the Public," G. Clarke Henderson writes in the third person he "regrets that the present compilation, though far superior to the imperfect affairs that have of late years been published, is not such as he would have wished, or as it would have been had a little more time been allowed for the task." Henderson clarified that the "entire city had to be canvassed... and that, too, after the "first of May," while that of the opposition was commenced EARLY IN 
APRIL... [this and ensuing advantages] enabled them to issue their publication a few days in advance of ours." Hence Smith's directory sold first and faster than Hope and Henderson's.

85 See Whitman's own Brooklyn Daily Times editorials on "The First of May" and "A Moving Article," published on p.2 of the editions for May 1, 1857, and April 19, 1858.

86 In his note "To the Public" in Hope and Henderson's Consolidated Brooklyn City Directory, G. Clarke Henderson claims that William Smith canvassed the Western District of Brooklyn early, allowing him to "arrange and print [these names] while the canvas of the Eastern was yet going on." Whitman, living on Classon Avenue in the Western District, would thus have been canvassed in the earlier part of the period from early April to early June.

87 Holloway and Schwarz miss this listing entirely. Holloway made other uncareful observations and notable errors in I Sit and Look Out. For example, he describes William Wood as "Whitman's successor" at the Times (232), and also notes that Wood was the author of an article published in 1908 entitled "Days Past in the Times Office" (202). In the article, Wood writes "Walt Whitman was only a fading memory in the Times office in 1871 "followed Whitman in the editorial seat, it was many years after Whitman's tenure ended.

88 Walt Whitman to Charles M. Skinner, January 19, 1885. Available on the Walt Whitman Archive (www.whitmanarchive.org, ID: loc.03812).

89 For a discussion of Whitman's contributions to Life Illustrated from April 12, 1856, to August "and possibly later," see Emory Holloway and Ralph Adimari, New York Dissected, by Walt Whitman; a Sheaf of Recently Discovered Nerwspaper Articles by the Author of Leaves of Grass (New York: R. R. Wilson, 1936), 7-9.

90 Holloway and Adimari, 179-184.

91 See Bowers, xxviii.

92 Whitman chronologies are particularly thin for the year 1858. See Krieg's Whitman Chronology, which has a single note for that year (37).

93 The Oxford English Dictionary cites this as a twentieth-century usage only.

94 Walt Whitman, Leaves of Grass 1860; The 150 th Anniversary Facsimile Edition, ed. Jason Stacy (Iowa City: University of Iowa Press), 185.

95 Roger Asselineau is among those who misunderstood the period of canvassing for the Brooklyn directories, and thus assumed that Whitman was listed as "copyist" in 1860 rather than the correct date of mid-1859. See The Evolution of Walt Whitman, trans. Richard P. Adams and the author (Cambridge, MA: Harvard University Press, 1960), 313. Further investigation of Whitman's work as copyist before publishing the third edition of the Leaves - rather than only afterward, as 
has been supposed - may yield new information regarding the influences on his new poems.

96 The poet's notebook entry of June 26 1859-“it is now time to Stir first for Money enough, to live and provide for $\mathrm{M}$ - . To Stir. - first write stories, and get out of this Slough"-makes more sense considering that he may not have had steady work for a month or more. See Notebooks and Unpublished Manuscripts, 1:405.

97 Though some scholars including Gay Wilson Allen claim that Bennett fired Whitman in 1859, Whitman's co-worker Frederick Huene explains that "Whitman resigned his place in consequence of articles which were very unfavorably criticized by ministers and church people, and about which he had quite a philosophical debate with Mr. Bennett." Times editor Charles Skinner also notes that Whitman resigned. See Allen, 215. For quotation from Huene, see the unsigned article "Sixty Years of Newspaper Making," 3. Skinner tells his version of the story in "Walt Whitman as an Editor," Atlantic Monthly 92 (1903), 679. Correspondence, 3:385-386.

98 Walt Whitman to Charles M. Skinner, January 19, 1885. Available on the Walt Whitman Archive (www.whitmanarchive.org, ID: loc.03812). 